\title{
BACK TO THE CEDAR FOREST: THE BEGINNING AND END OF TABLET V OF THE STANDARD BABYLONIAN EPIC OF GILGAMEŠ
}

\author{
F. N. H. Al-Rawi and A. R. George (SOAS, University of London)
}

In memory of W. G. Lambert, who led the way

The fifth tablet of ša naqba imuru, the Standard Babylonian Epic of Gilgameš, tells the story of Gilgameš and Enkidu's encounter with Humbaba, the guardian of the Cedar Forest: how the two heroes entered his realm, took him captive, laid waste to his trees, and returned home bearing his head as a trophy. The tablet is securely represented by two manuscripts, one Neo-Assyrian from Nineveh and the other Late Babylonian from Uruk. In the critical edition these are given the sigla MS H and MS dd respectively (George 2003: 602-3). They are identified as manuscripts of Tablet $\mathrm{V}$ because both bear as catch-line the verse imsi malêšu ubbiba tillēšu, which is the incipit of a part of the poem identified by colophons as Tablet VI, and because the colophon of MS dd itself identifies it as Tablet V, im 5.kam.ma (George 2003: 741).

The two manuscripts differ in their point of onset. The incipit of MS H is-as we read it-izzizūma inappatū qišta, ${ }^{1}$ that of MS dd Humbāba pâšu ìpušma iqabbi izakkara ana Gilgāmeš. It was proposed accordingly that MS H from Nineveh and MS dd from Uruk represented two different textual traditions, one current in Assyria, the other in Uruk (von Weiher 1980: 90) or in Babylonia generally (George 2003: 403). A tablet identified in 2011 by Farouk Al-Rawi in Suleimaniyah in Iraq, in the territory of the Kurdistan Regional Government, refutes that proposition, for it is Neo-Babylonian and commences with the same incipit as Assyrian MS H.

Before describing the new tablet, it is necessary to consider the place of two other fragments from Nineveh, the large piece MS AA and a small fragment that duplicates part of it, MS DD. In the sequence of fragments that describe Gilgameš and Enkidu's approach to the Cedar Forest, and their entry within, the place of MSS AA and DD in respect to MS H has not been settled beyond doubt, despite the near unanimity of scholars throughout the last century. It was clear from a physical inspection that MSS H and AA are very similar and can be attributed to the same scribe (George 2003: 402). In George's description of the manuscripts of the Standard Babylonian poem they are both categorized as Type D manuscripts, probably older than the seventh century (George 2003: 384). MS $\mathrm{H}$ contains a passage in which Gilgameš and Enkidu arrive at the Cedar Forest and admire its luxuriance, one of the rare passages of Babylonian narrative poetry that is given over to the description of nature. MS AA contains a conversation in which Gilgameš exhorts Enkidu to prepare for combat. Most scholars have placed the text of MS

1. Or, izzizūma ina-pattu qišti (most recently Streck 2007: 413-14). 
AA before that of MS H, but a few have placed it after. Part of the history of scholarship on this point has been summarized in the critical edition (George 2003: 402 n. 65), but a fuller account will be instructive.

George Smith, the pioneering Assyriologist who in the 1860s and 1870s identified many fragments of the Gilgameš epic in the British Museum's Kuyunjik collection, gave the world a first glimpse of the poem in translation in his Chaldean Account of Genesis (1876). MSS H and AA were among his discoveries, and he translated them in that order, $\mathrm{H}$ first and AA second, as the opening of Tablet V, remarking that "about 10 lines" were lost between them in col. i (Smith 1876: 214). This remark can only have been made as a consequence of Smith's physical comparison of the two pieces, for there was no textual basis for it. At that juncture, MS AA lacked the right-hand fragment that has ten lines of another column of text, so that for col. ii of his Tablet V, Smith had only the very fragmentary lines of MS H col. ii.

By the time Paul Haupt published the first cuneiform copies of MSS H and AA in the first volume of Das babylonische Nimrodepos (1884), the fragment lacking in 1876 had been joined to MS AA as its col. ii (H = Haupt 1884: 24-26 no. 11, AA = 27-28 no. 12). In an annotation to MS AA, Haupt accordingly identified this piece as holding the ends of the first two columns of Tablet V. He agreed with Smith that MS AA followed MS H after a short gap: "Dem Anschein nach schloss sich dieses Stück ziemlich genau an Nr. 11, K. 3252 [= MS H] an, so dass zwischen der letzten Zeile (17) von Nr. 11, Col. I auf S. 24 und der ersten Zeile (25) der hier folgenden Stückes [= MS AA] etwa 9 Zeilen weggebrochen sind" (Haupt 1884: 27). Thus the two scholars who did most to reconstruct and publish the text of Gilgameš in the nineteenth century agreed that MS H col. i was succeeded by MS AA col. i after a short break of nine or ten lines. Further, on the grounds of their physical appearance, Haupt considered that they were both parts of the same original six-column tablet.

Haupt collated his published copies in 1890 . On this occasion he noted that the last-preserved line of MS AA col. i was the same as the first line of MS H col. i (Haupt 1890: 110). This discovery led him to consider a contrary opinion, that MS AA col. i might instead preserve the end of Tablet IV, with the last line acting as the catch-line of Tablet V. This arrangement of the text would mean that what he had identified in 1884 as MS AA col. i was actually col. vi, and what he had understood to be col. ii was really col. v. Again, the text was too fragmentary to solve the matter, but Haupt concluded that such a reordering of the passages was extremely dubious (“äusserst zweifelhaft”). His reluctance to adopt it seems to have stemmed from his (very accurate) observation that the surviving written surface of MS AA is flat, and thus part of the tablet's obverse face. He adds opaquely, "Ob die beiden Columnen von K. 8591 [= MS AA] der Vorderseite oder Rückseite angehören, lässt sich nur angesichts des Originals entscheiden” (1890: 110). One senses that someone who had not seen the tablets, as Smith and Haupt had, had concluded from Haupt's copies that, if MS AA “i 45” = MS H i 1, then if MS H was Tablet V, MS AA must necessarily be from the reverse of Tablet IV; that this person had communicated this conclusion to Haupt with some force; and that Haupt felt obliged to air it in print, even though he knew it to contradict what he had observed with his own eyes, that $\mathrm{K}$ 8591 was an obverse fragment.

The first scholar to publish a transliteration of the whole poem of Gilgameš, as then extant, was Peter Jensen in his extraordinary anthology of Assyrisch-babylonische Mythen und Epen (1900: 116-265). Jensen did not accept Smith and Haupt's consensus that MS H and MS AA were both parts of Tablet V. Adopting instead the very notion that Haupt considered but repudiated in 1890, he placed the large piece of MS AA at the end of Tablet IV (1900: 156-59). On the advice of C. H. W. Johns, Jensen rejected the join of the small right-hand fragment to MS AA published by Haupt in 1884 (p. 28) and, on grounds of content, left it in Tablet V (1900: 153, 159). Johns' advice to Jensen was false: the join that he denied was confirmed by later copyists. The placing of MS AA in Tablet IV instead of Tablet V, however, had taken root in Gilgameš scholarship.

The next serious translator of Gilgameš was Arthur Ungnad. He followed Jensen's ordering of MSS H and AA but, because the join that Johns and Jensen repudiated had already been proved correct (probably by Pinches), he was naturally obliged also to place the text of MS AA's right-hand column in Tablet IV (Ungnad 1911:25-27). In a rare excursion into Assyriology, entitled "Einige Bemerkungen zur Einreihung der Gilgamešfragmente," the eminent Old Testament scholar Sigmund Mowinckel followed suit (Mowinckel 1916: 264-65). Campbell Thompson’s 
edition of 1930 agreed with Jensen, Ungnad, and Mowinckel in placing MS AA in Tablet IV (Thompson 1930: 34-35). His cuneiform copy added slightly to knowledge by amalgamating the right-hand column of MS AA with the text of the previously unpublished duplicate MS DD (1930 pl. 15 K 8591 "col. v" // K 13525).

Schott's German translation of 1934 (1934a) for the mass-market publisher Reclam was dedicated to Jensen and justified in an extensive article entitled "Zu meiner Übersetzung des Gilgameš-Epos” (1934b). His opening words on Tablet IV were an emphatic restatement of Jensen's position: "Dazu gehört mit voller Sicherheit K 8591 [= MS AA] und sein Duplikat K 13525 [= MS DD]: die Fangzeile von K 8591 = Zl. 1 v. K 3252+8561 [= MS H]" (Schott 1934b: 113). Schott's "complete certainty" is a noteworthy rejection of Haupt's "extreme doubt." Influential translations also followed Jensen and Schott: among them were Contenau's in French (1939: 97-98); and in English Heidel's, first published in 1946 (Heidel 1963: 44-45), and Speiser's, which graced Pritchard's anthology of Ancient Near Eastern Texts Relating to the Old Testament, first published in 1950 (Speiser 1969: 82). Schott's translation was itself revised by von Soden, who kept the Reclam translation abreast of new discoveries of text for half a century (Schott and von Soden 1982). In his article “Beiträge zum Verständnis des babylonischen Gilgameš-Epos," a counterpart to Schott 1934b, von Soden maintained Schott's position regarding the placing of MSS AA and DD in Tablet IV (von Soden 1959: 224).

A paper given in 1958 to the $7^{\mathrm{e}}$ Rencontre Assyriologique Internationale by J. V. Kinnier Wilson, and published in the proceedings (Kinnier Wilson 1960), revived the case for placing MS AA in Tablet V, after MS H, citing content and physical appearance. Kinnier Wilson's comments on the physical appearance of MS AA were in agreement with those two others who had actually examined the fragment, that is, Smith and Haupt, and more strongly stated: "K. 8591 [= MS AA] is a certain Obverse. The preserved surface of the fragment does not exhibit any degree of curvature" (1960: 105). The correctness of this observation can now be verified without travelling to London, from the photographs posted online at the Cuneiform Digital Library Initiative (www.cdli.ucla.edu/P273227). To circumvent the problem caused by the appearance of the incipit of Tablet V at the bottom of MS AA, that is, well into Tablet V, Kinnier Wilson proposed that there were two recensions of Tablet V, one beginning with K 3252+ (MS H) i 1 izzizūma inappatū qišta and another in which this same line fell "some 40 to 50 lines" later. In this way he reconciled the fragments' physical properties with Jensen's ordering of the passages of text inscribed on them. Kinnier Wilson's arguments were subsequently rejected by Landsberger, who in his study of Tablets IV and VII reasserted the position, by this time orthodox, that MS AA belonged in Tablet IV (Landsberger 1968: 104-5 n. 27).

Strengthened by Landsberger's intervention, the orthodoxy persisted throughout the remainder of the twentieth century, informing the many translations that were published in its last four decades. A lone voice of doubt was Johannes Renger (1987: 321), who criticized Landsberger's rejection of Kinnier Wilson's argument but did not find a definitive solution to the conundrum set by the appearance of the incipit of Tablet $\mathrm{V}$ at the bottom of the left-hand column of MS AA. The critical edition that took Gilgameš studies into the new millennium adopted the conventional ordering of the passages, but with some reservation, noting in regard to MS AA the "flatness of its surface" and remarking, "provisionally, then, MS AA remains in Tablet IV but more text is needed to clarify the succession of episodes" (George 2003: 402 with n. 65). That desire is now amply met with the Neo-Babylonian manuscript of Tablet V identified by Farouk Al-Rawi.

This long history of scholarship on the order and relationship of the fragments MSS H and AA provides a salutary lesson. The new manuscript presented here demonstrates that Smith's and Haupt's instincts were right, for it proves incontestably that the text of MS AA continues that of MS H after a short gap, and that both are witnesses of cols. i and ii of Tablet V as it was known at Nineveh. It thus confirms what the fragment MS AA told Smith, Haupt, and Kinnier Wilson when they interpreted it as an archaeological object and identified it as part of an obverse.

Understanding cuneiform tablets as archaeological objects is a practice that had few exponents for much of the twentieth century, when Assyriologists too often gave all their attention to the inscribed text as a self-contained intellectual resource disembodied from the medium on which it was written. The customary technique of penand-ink drawing of the inscribed surface - and often only the inscribed surface-in two dimensions made it easy for scholars to ignore the physical properties of the object on which that inscribed surface appeared. But even 
those whose eyes told them that MS AA must be an obverse fragment failed to alight on an explanation of how it could contain the apparent incipit of Tablet $\mathrm{V}$ in the last line of its left-hand column.

There is a simple explanation. The line at the bottom of the column on MS AA that apparently repeats the incipit of Tablet V, the line that, from Jensen onward, most scholars took for a catch-line of Tablet IV, is not the same line at all, for it occurs fifty-two lines later in the poem. If it is identical to the line in question, izzizuma inappatū qišta, it is a repetition of the line that had previously occurred as the incipit. Repeated lines feature strongly in the composition of Babylonian narrative poetry (Hecker 1974: 146-60). The present instance of repetition would serve to reassert the atmosphere of wonder that was initiated by the incipit. However, the line on MS AA is damaged, so that the first word is entirely missing and the second not completely certain: [...] inapattū(?) qišta. It may yet be that this line is similar to the incipit of Tablet $\mathrm{V}$ but not a verbatim repetition.

Now that Smith and Haupt are vindicated in their respective placing of MSS H and AA, it is self-evident that the two fragments should be treated as Haupt proposed, as upper and lower fragments from the left part of the same six-column tablet. The cuneiform copies made for the critical edition and published there on separate pages (George 2003: pls. 70 and 72) are therefore republished here together in their proper relation and with a new line numbering (fig. 1). Since they are parts of the same manuscript, the two fragments should henceforth bear the sigla $\mathrm{H}_{1}(\mathrm{~K} 3252+$, formerly $\mathrm{H})$ and $\mathrm{H}_{2}$ (K 8591, formerly AA).

\section{The New Tablet}

The tablet presented here is the left half of a six-column tablet inscribed in a fine and delicate Neo-Babylonian hand with a copy of Tablet V of the Standard Babylonian Epic of Gilgameš. It was acquired by Suleimaniyah Museum in the jurisdiction of the Kurdish Regional Government in 2011 with other Babylonian antiquities of the kind found in southern Iraq; its exact provenance is therefore unknown. The script and circumstances of acquisition make it highly probable that it was unearthed at a Babylonian site. The tablet measures $11.0(\mathrm{~h}) \times 9.5(\mathrm{w}) \times 3.0$ (thickness) cm, and now bears the Suleimaniyah Museum number T.1447.

The tablet was identified in November 2011 by Farouk Al-Rawi, who quickly communicated to George his photographs, preliminary decipherment and hand copy. The present article is the fruit of a collaboration that culminated in a joint study of the tablet in Suleimaniyah in November 2012. Over five days we read the tablet together, adjusted the copy and transliteration and took new photographs. The revised drawings and new photographs are presented here as figs. $2-5$.

For the opportunity to study and publish this important new addition to Gilgameš, the authors wish to thank Her Excellency Hero Ibrahim Ahmad, the First Lady of Iraq. Her generous patronage of the Directorate of Antiquities in Suleimaniyah underpins its activities and supports Farouk Al-Rawi's travel to Suleimaniyah and his work there. Our collaboration owes much in addition to the kind help, ready hospitality, and warm friendship freely given by Kamal Rashid Rahim, Director of Antiquities in Suleimaniyah, by Hashim Hama Abdullah, Director of the Suleimaniyah Museum, and by the staff of the museum, especially its cuneiform section. ${ }^{2}$

As already revealed, what remains of the obverse (cols. i-ii) of T.1447 duplicates the Neo-Assyrian fragments MSS $\mathrm{H}$ (now $\mathrm{H}_{1}$ ), AA (now $\mathrm{H}_{2}$ ) and DD of the critical edition, allowing them to be placed in order and plugging the gaps between them. It also shows that the recension of Tablet $\mathrm{V}$ that begins with izzizūma inappatū qišta was current in Babylonia, as well as in Assyria. The reverse (cols. v-vi) duplicates parts of the reverse (cols. iv-vi) of MS dd, the Late Babylonian tablet excavated at Uruk that begins with the incipit Humbāba pâšu ìpušma iqabbi

2. In addition, George's travel to Iraqi Kurdistan was partly offset by a research fund made available to him by the School of Oriental and African Studies, University of London. In working on the text of T.1447 he benefited much from reading it with London colleagues and visitors in the London Cuneiforum, and again in Heidelberg with Prof. Dr. Stefan M. Maul. Errors remain the responsibility of the authors. 


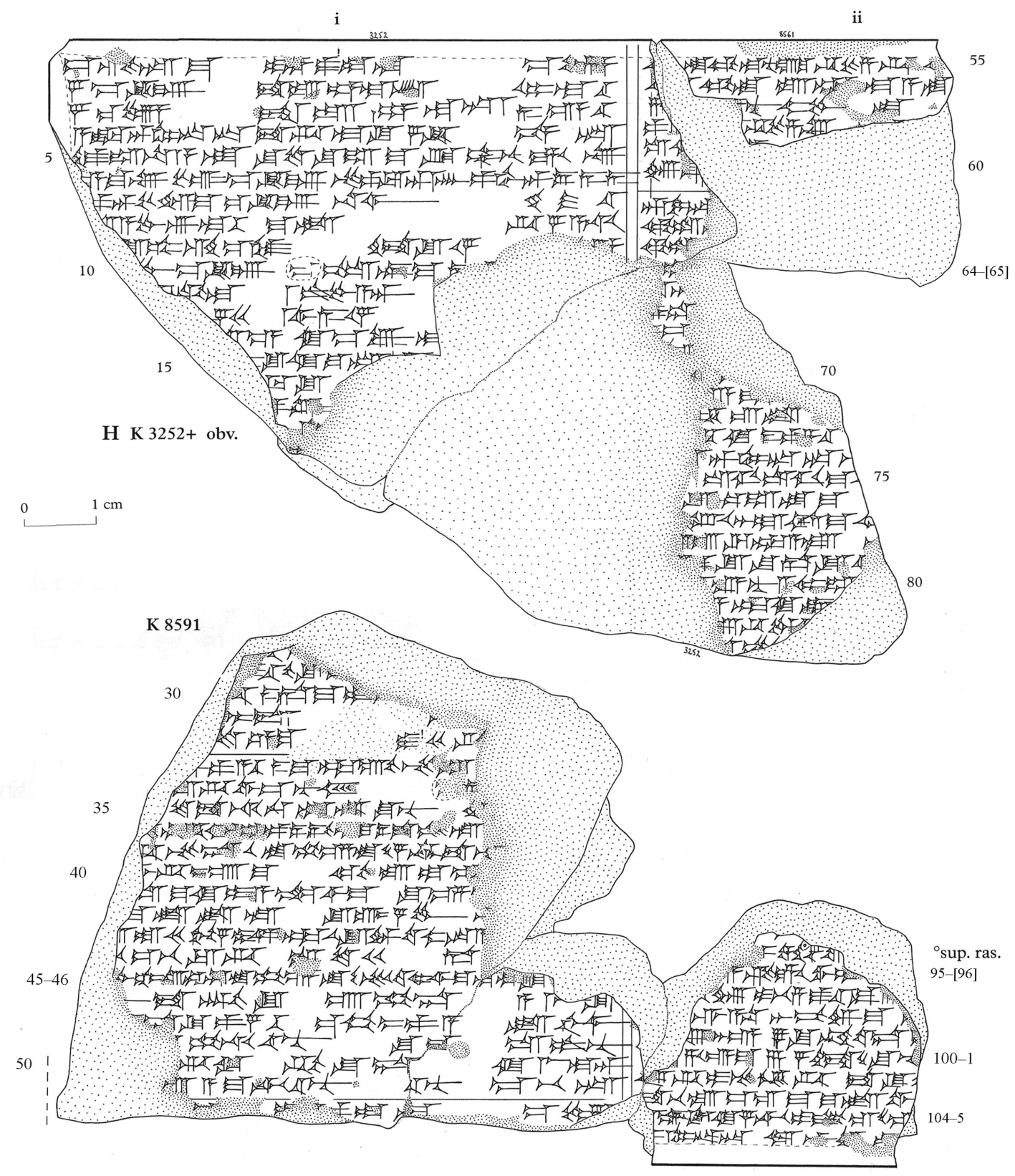

Fig. 1. SB Gilgameš Tablet $V$ from Nineveh, $M \mathrm{HS}_{1}(+) \mathrm{H}_{2}$ (formerly $\mathrm{H}$ and AA), adapted from George 2003: pls. 70 and 72. 
izakkara ana Gilgāmeš. The revised reconstruction of Tablet V yields a text that is nearly twenty lines longer than formerly supposed. ${ }^{3}$

The most interesting addition to knowledge provided by the new source is the continuation of the description of the Cedar Forest, one of the very few episodes in Babylonian narrative poetry when attention is paid to landscape. The cedars drip their aromatic sap in cascades (11. 12-16), a trope that gains power from cedar incense's position in Babylonia as a rare luxury imported from afar. The abundance of exotic and costly materials in fabulous lands is a common literary motif. Perhaps more surprising is the revelation that the Cedar Forest was, in the Babylonian literary imagination, a dense jungle inhabited by exotic and noisy fauna (17-26). The chatter of monkeys, chorus of cicada, and squawking of many kinds of birds formed a symphony (or cacophony) that daily entertained the forest's guardian, Humbaba. The passage gives a context for the simile "like musicians" that occurs in very broken context in the Hittite version's description of Gilgameš and Enkidu's arrival at the Cedar Forest. ${ }^{4}$ Humbaba's jungle orchestra evokes those images found in ancient Near Eastern art, of animals playing musical instruments. ${ }^{5}$ Humbaba emerges not as a barbarian ogre and but as a foreign ruler entertained with music at court in the manner of Babylonian kings, but music of a more exotic kind, played by a band of equally exotic musicians.

Another passage (61-72), though consisting only of half lines, seems to confirm the point, already known from MS dd i 5 (formerly V 89, now V 119), that Enkidu had spent time with Humbaba in his youth. Humbaba, having become aware of the presence of intruders in his domain, appears to guess that it must be Enkidu returned home, perhaps even to be excited by the thought of the coming reunion. If it is right to read into these fragmentary lines a tender reference to their earlier life together, then Humbaba's subsequent betrayal by Enkidu, who has brought with him a hostile alien, the king Gilgameš, becomes all the more poignant.

The aftermath of the heroes' slaying of Humbaba is now better preserved (300-308). The previously available text made it clear that Gilgameš and Enkidu knew, even before they killed Humbaba, that what they were doing would anger the cosmic forces that governed the world, chiefly the god Enlil. Their reaction after the event is now tinged with a hint of guilty conscience, when Enkidu remarks ruefully that [ana] tušār ništakan qišta, "we have reduced the forest [to] a wasteland" (303). The anxiety about offending the gods seems to a modern reader compounded by ecological regret. Enkidu goes on to imagine the angry questions that Enlil will ask them when they arrive home: minûu uzzakunūma taraḩhișa qišta, "what was this wrath of yours that you went trampling the forest?" (306). In the theme of the angry gods, the poems about Humbaba in both Sumerian and Akkadian already displayed an ethical ambivalence toward the expedition to his Cedar Forest, arising from what one commentator has called the "double nature" of the forest's guardian as ogre and servant of Enlil (Forsyth 1981: 21). This newly recovered speech of Enkidu adds to the impression that, to the poets' minds, the destruction of Humbaba and his trees was morally wrong.

It is unsurprising then that the pair immediately kill the only witnesses to their crime, the "seven sons of Humbaba" (307). The "seven sons" are a productive motif in ancient Mesopotamia, most often occurring in the mythology of Enmešarra (see now Lambert 2013: 213-14). Enmešarra was a divine ancestor whose insurrection was suppressed by a junior god (Ninurta, later Marduk), who killed both him and his seven sons. The myth informs learned expository texts (Livingstone 1986: 152-53) and is elaborated in two newly edited Babylonian narrative poems (Lambert 2013: 281-98 “Enmešarra’s Defeat”; 326-29 “The Defeat of Enutila, Enmešarra, and Qingu”). In Gilgameš the motif personalizes the forces known elsewhere in the poem as Humbaba's seven melemmī "auras," pulhātu "terrors," or namrirrū "radiant beams," which in one Old Babylonian fragment are left running around in the forest after their owner's capture (OB Ishchali 16'-17', ed. George 2003: 262). Only here in SB V 307 are these

3. The synoptic transliterations ("scores") of SB Gilgameš IV and V posted online at www.soas.ac.uk/gilgamesh have been revised to take account of the advances in knowledge afforded by MS ff, and show for Tablet V a reconstructed text of 324 11. (previously 302 ).

4. As translated by Beckman 2001: 160. A transliterated text and translation are online at the Hethitologie Portal (http://www.hethiter.net/: CTH 341.III.1) in the edition by E. Rieken (2009 §18"'" 132); I owe knowledge of this resource to Mark Weeden.

5. With particular reference to monkey musicians see Dunham 1985; Spycket 1998. 
supernatural forces, part demon, part tree, called Humbaba's "sons." When they are slain later in the same Old Babylonian fragment, the line differs materially from SB V 307 only and precisely in the lack of the word märēšu "his sons" (OB Ishchali 35'b: ištūma sebet inērü "as soon as he had slain (all) seven."

The use of the motif of the Seven Sons in the episode of Gilgamešs combat with Humbaba lends a mythological gloss to the story, encouraging it to be read in the knowledge of the myth of Enmešarra. The comparison reveals a subtext: in establishing a new world-order, favorable to human society, the hero must necessarily do away with the old order, personified by a hoary victim and his seven sons. This view, in which Humbaba is considered not an innocent victim but a repository of evil who must be destroyed for the common good, informs other passages of the poem (e.g., SB III 54: mimma lemnu ša tazerru uhallaq ina mäti, "he will annihilate from the land the Evil Thing that you hate"). It expresses exactly the opposite of the idea raised in the preceding speech of Enkidu, that the two heroes do wrong in killing Humbaba.

The interpolation of the word "his sons" in SB V 307, vis-à-vis OB Ishchali 35'b, is perhaps a deliberate ploy to make explicit the allusion to the mythology of Enmešarra. In just a few lines Humbaba makes the transition from innocent victim to wicked terror-maker. There is a psychological insight at work, for the transition matches the development of a guilty party's thoughts: understanding that he has murdered, the murderer justifies what he has done by finding his victim deserving of death. The passage of Enkidu's speech and the immediately following line thus mark the poet out as a shrewd observer of the human mind, and add to the poem's reputation for insight into the human condition.

In continuation of the scheme of sigla employed in the critical edition (George 2003: 531-34), the new manuscript is hereinafter referred to by the siglum MS ff. The following transliteration conforms to the text of MS ff, with restorations from the other extant manuscripts of Tablet V. A synoptic transliteration ("score") of the all the manuscripts, line by line, is posted online at www.soas.ac.uk/gilgamesh. 
Transliteration of Suleimaniyah Museum T.1447 = SB Gilg. V MS ff

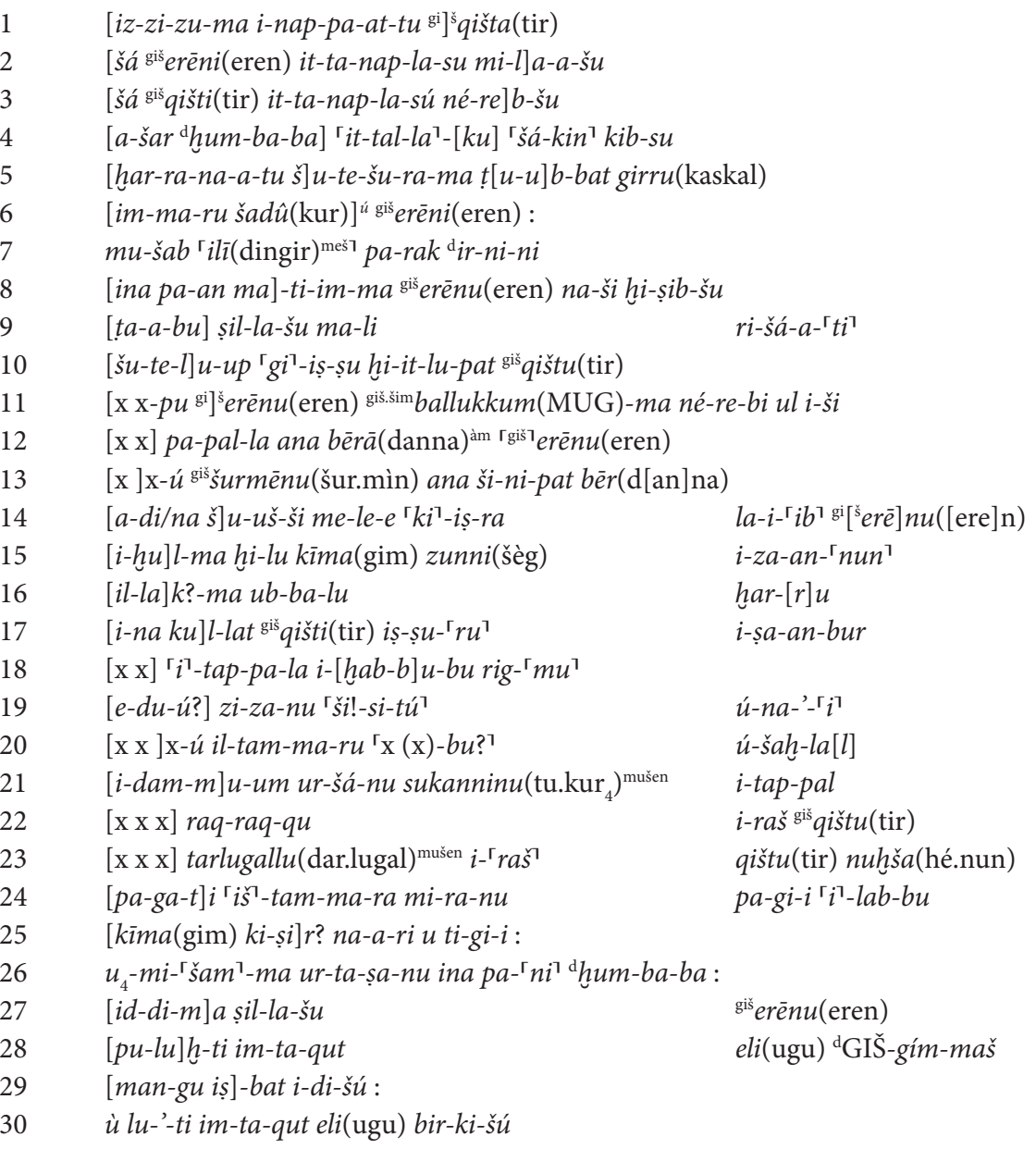

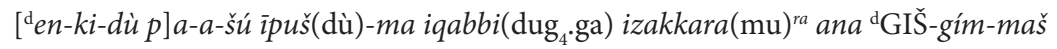

[i nit-tar]-da a-na qé-reb

[qat-ka pi]-te-ma i niš-kun tuk-ka

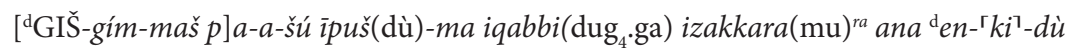

[am-me-ni ib-ri] pi-is-nu- ${ }^{\top} q i \bar{s}^{\top}$

NU-šub-ba-[a]m-ma

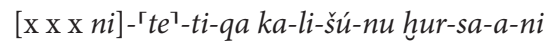

$[\mathrm{x} \times(\mathrm{x}) \mathrm{x} \mathrm{x}-t] a-t i$

i-na pa-ni-ni

$[\mathrm{x} \times \mathrm{x} \times \mathrm{x} \times \mathrm{x}]-r i-i s^{6}$ nim-mar

$n u-u ́-r a$

6. Seemingly incompatible with $\mathrm{H}_{2}:\left\ulcorner l a^{\top}-m a\right.$ ni-「it-tah ${ }^{\top}-s u[\ldots .]$. 
Translation, using all extant manuscripts

They stood there marvelling at(? $)^{7}$ the forest, observing the height of the cedars, observing the way into the forest.

Where Humbaba came and went there was a track, the paths were in good order and the way was well trodden.

They were gazing at the Cedar Mountain, dwelling of gods, throne-dais of goddesses:

[on the] face of the land the cedar was proffering its abundance, sweet was its shade, full of delight.

[All] tangled was the thorny undergrowth, the forest a thick canopy, cedars (and) ballukku-trees were [so entangled,] it had no ways in.

For one league on all sides cedars [sent forth] saplings, cypresses $[. .$.$] for two-thirds of a league.$

The cedar was scabbed with lumps (of resin) [for] sixty (cubits') height, resin [oozed] forth, drizzling down like rain,

[flowing freely(?)] for ravines to bear away. [Through] all the forest a bird began to sing:

[...] were answering one another, a constant din was the noise, [A solitary(?)] tree-cricket set off a noisy chorus,

[...] were singing a song, making the ... pipe loud. A wood pigeon was moaning, a turtle dove calling in answer.

[At the call of] the stork, the forest exults, [at the cry of] the francolin, the forest exults in plenty.

[Monkey mothers] sing aloud, a youngster monkey shrieks: [like a band(?)] of musicians and drummers(?), daily they bash out a rhythm in the presence of Humbaba.

As the cedar [cast] its shadow, [terror] fell on Gilgameš.

[Stiffness took] a grip of his arms, and feebleness beset his legs.

[Enkidu] opened his mouth to speak, saying to Gilgameš:

"[Let us go] into the midst of the forest, [set] to it and let us raise (our battle) cry!"

[Gilgameš] opened his mouth to speak, saying to Enkidu:

"[Why,] my friend, are we trembling like weaklings, [we] who came across all the mountains?

[Shall ...] ... before us? [...] shall we see the light?"

7. Or, "at the edge of."

8. So ff; $\mathrm{H}_{2}$ has a line beginning "Before we have withdrawn ..." 


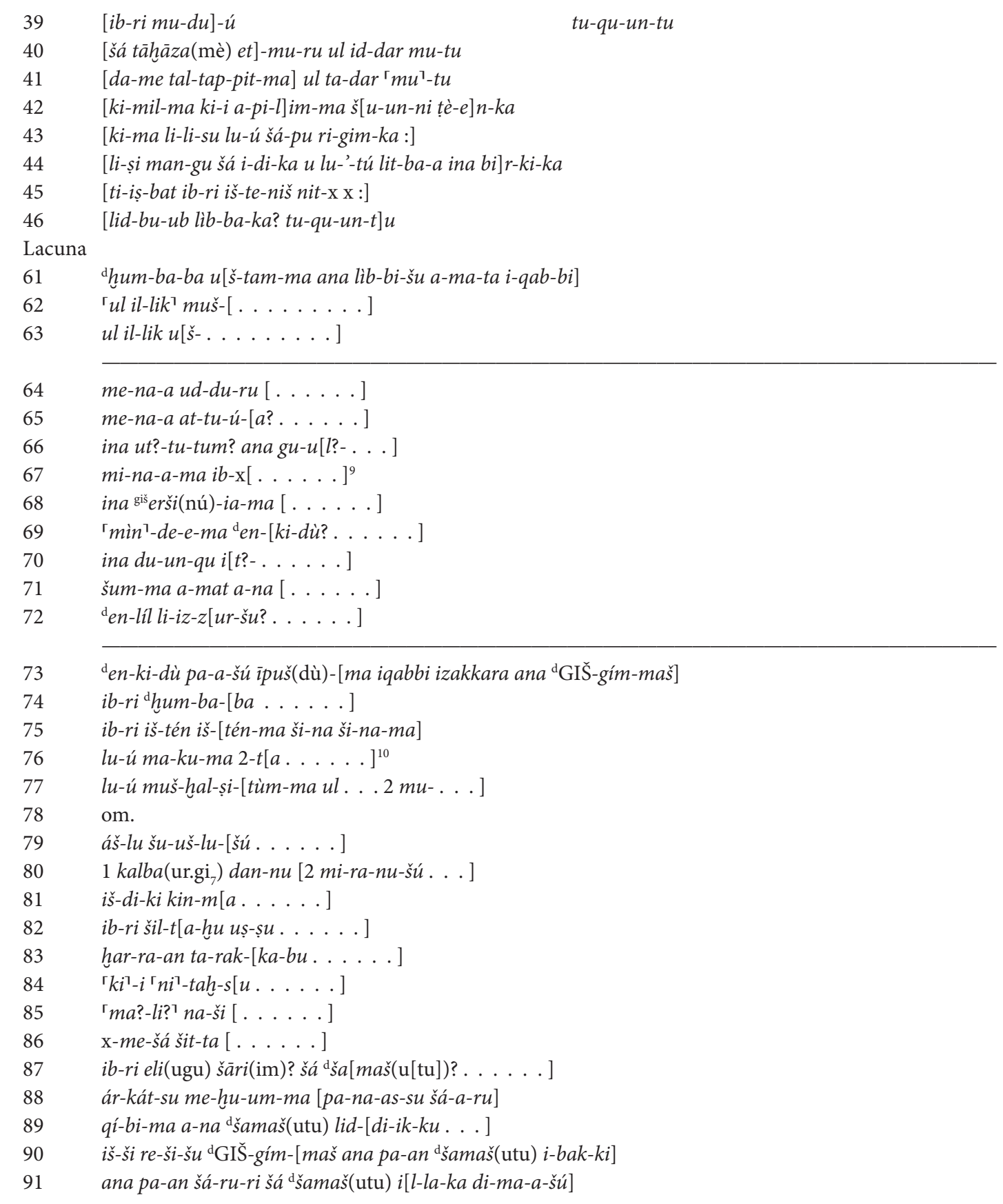

9. $\mathrm{H}_{1}$ begins differently: $\mathrm{x}-d u[\ldots]$.

10. Differently $\mathrm{H}_{1}:[2]\left\ulcorner l u^{\top}-b a-r a-t u-m a[\ldots]\right.$. 
Enkidu replies:

39 "My [friend] is one who is experienced in combat,

40 one who has been in battle has no fear of death.

41 You have been smeared in [blood,] so you need not fear death:

42 [wax] wrathful, and like a very dervish go into a frenzy.

43 Let [your shout] boom loud [like] a kettledrum!

$44 \quad$ Let stiffness leave your arms and feebleness arise [from] your legs!"

Gilgameš:

45 "Take hold of me, my friend, as one we shall [...]

46 [Let] your mind dwell on combat!"

Lacuna

61 Humbaba [talked with himself, speaking a word:]

62 "Did not a ... go [.... ? ]

63 Did not $[\ldots$ go ..... ? $]$

64 Why are [...] perturbed [and ... ?]

65 Why are my own $[\ldots \ldots$ ?]

66 In terror(?) for ... [.....]

67 How indeed ... [.... ? ]

68 In my very bed $[\ldots \ldots]$

69 For sure Enkidu(?) [.....]

70 In goodwill he $[\ldots \ldots]$

71 If a word to $[\ldots \ldots$. .

72 May Enlil curse [him ...... !]”

73 Enkidu opened his mouth [to speak,] [saying to Gilgameš:]

"My friend, Humbaba [....... $]$ one friend is one alone, but [two are two!]

Though they be weak, two $[\ldots \ldots,]^{11}$ [though one alone cannot climb] a glacis slope, two [...]

Two triplets $[\ldots \ldots \ldots .$. a three-ply rope [is not easily broken.]

As for a strong dog, [its] two pups [will overcome it(?).]

Fix firm your stance $[\ldots \ldots$....

My friend, an arrow's dart [..... . ]

The journey that you are $[$ making ...... $]$

When we have departed $[\ldots \ldots]$ $\ldots$ is borne $[\ldots \ldots]$

Its ... two $[\ldots \ldots]$ My friend, on the winds(?) that Šamaš [...]

His rear is a tempest, [his front is wind.] Speak to Šamaš, that he may [give you his thirteen winds(?)!]"

Gilgameš lifted up his head, [weeping before Šamaš, ]

91 [his tears] flowing before the rays of the sun.

11. So ff; $\mathrm{H}_{1}$ : "[Two] garments, indeed, [......]" 


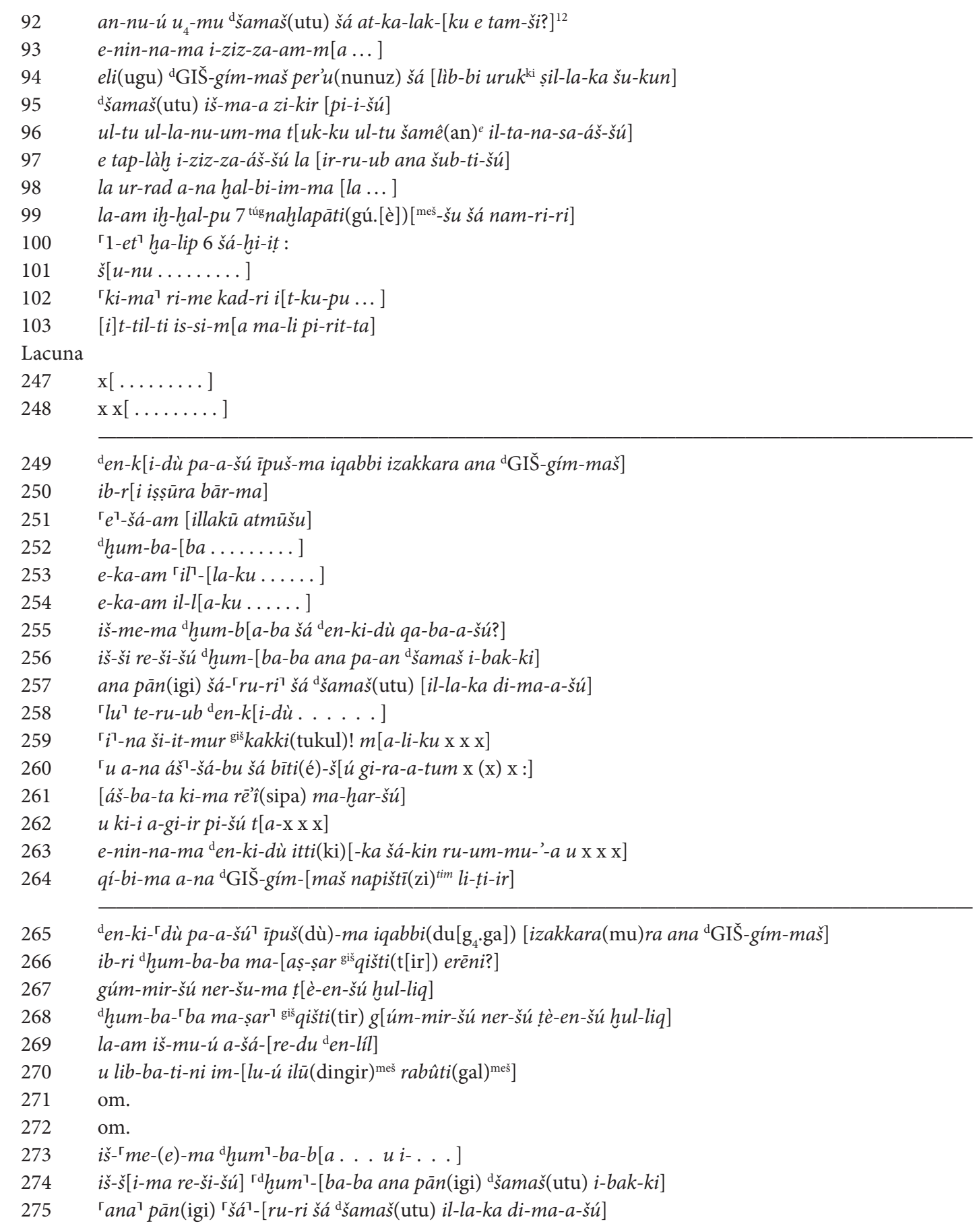

12. DD has a different line: $\left[u_{4}-m a\right.$ šá lib-b]i uruk $k^{\mathrm{ki}}$ taq-bu-[ni e tam-ši? ]. 
"[Do not forget] that day, O Šamaš, that I placed my trust in you! $!^{13}$ Now come to my aid and [......]

Upon Gilgameš, scion from Uruk's midst, [place your protection!]" Šamaš heard what [he] had spoken, straight away a voice [cried to him from the heavens:]

"Fear not, stand against him! He must not [enter his dwelling,] he must not go into the grove, he must not [..., ]

before he has wrapped himself ${ }^{14}$ in his seven cloaks [of radiance!] One he is wrapped in, six he has divested."

They $[\ldots \ldots \ldots \ldots$,

like a fierce wild bull, ready to charge [...]

He bellowed once, and it was (a bellow) full of terror, Long lacuna

\footnotetext{
13. So ff; DD: "[Do not forget the day that] you spoke [to me] in Uruk!"

14. So ff; H: "[He must not] wrap himself."

15. So ff; dd omits line.
} 


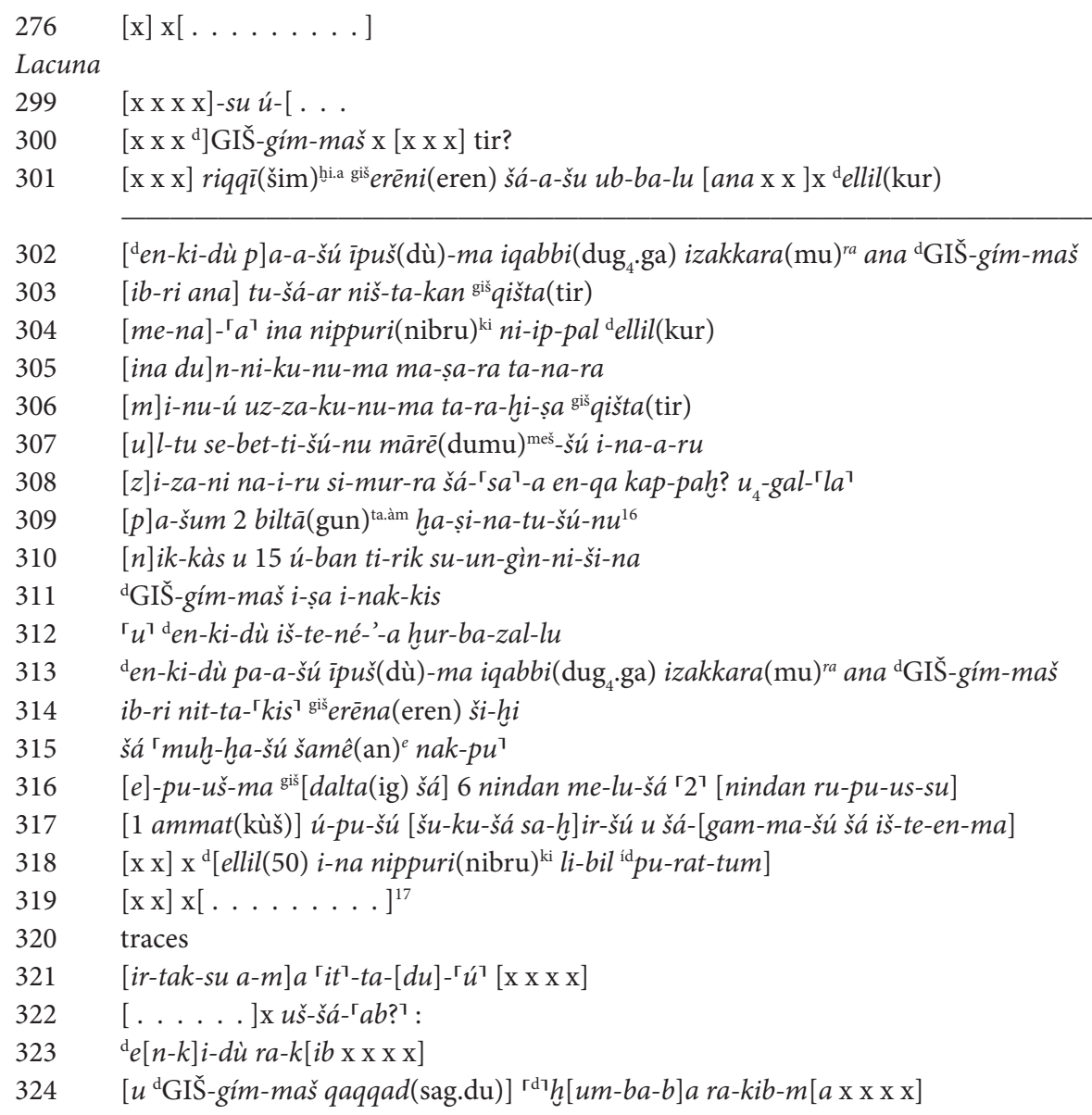

unplaced line inserted in the margin between cols. $\mathrm{v}$ and vi: [... ]-ta-ki kad?-ra? i-ma-ḩar- ${ }^{\top} \check{s}^{\top}{ }^{\top}$

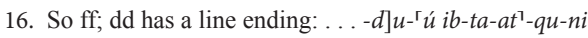

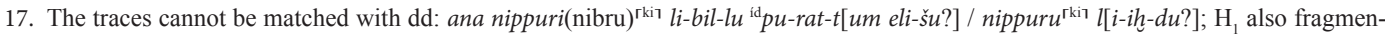
tary: .. .]x át-man $[\ldots$ 


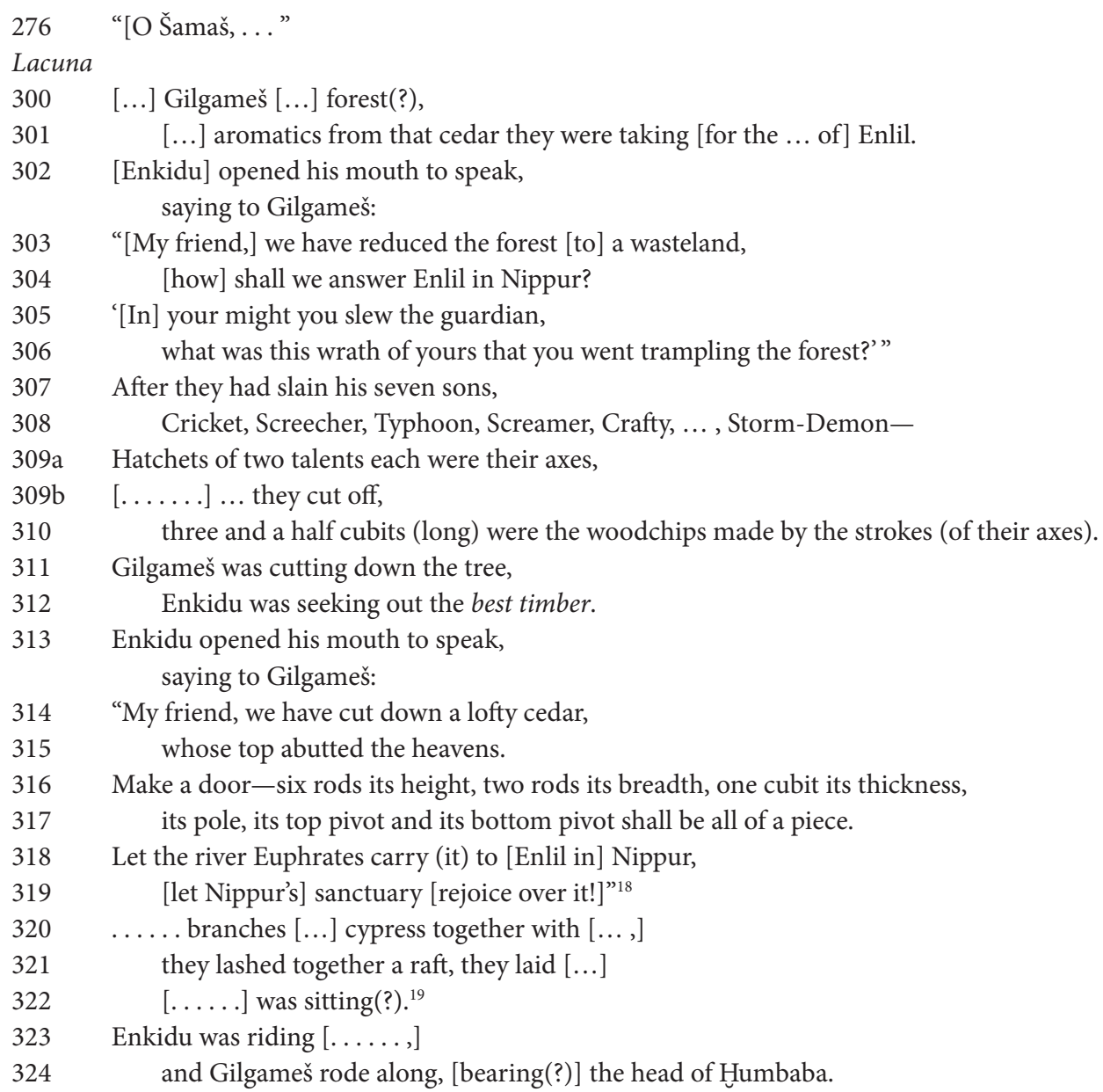

VI 1 He washed his matted hair, he cleaned [his equipment.]

\section{Notes on the Text}

14. The noun $l a^{\prime} b u$ is recognized as sometimes denoting a medical condition marked by disfigurement of the skin (Stol 2007: 11); its symptoms were unattractive enough to make a husband break off marital relations $(\mathrm{CH}$ $\$ 148$ ). The cognate verb is customarily supposed to signify a subject's “infection” with la'bu (or li'bu). The present passage suggests instead that it refers to something visible that might even be seen on a tree trunk. We would thus take the verb to denote the external symptoms of $l a^{\prime} b u$ and $l i b u$ disease: disfigurement of the skin, applied figuratively in this line to describe the scabby blisters that form where resin seeps through a cedar's bark. In this analysis the verb belongs to the empirical world of symptoms, not the deductive arena of diagnosis.

18. So $\mathrm{H}_{1}$; dd: "Let the Euphrates carry it to Nippur, let Nippur [rejoice over it!]"

19. So ff; $\mathrm{H}$ uncertain, dd omits line? 
19. The insect zizānu occurs as a feature of the Cedar Forest elsewhere in Gilgameš: later in this tablet, where it is the name of one of Humbaba's seven sons (V 308), and in broken context in an unprovenanced Old Babylonian tablet (OB IM obv. 13 zi-za-na-am, ed. George 2003: 268). It is conventionally understood as a kind of locust or cricket, no doubt because classed in Sumerian in the category of buru "locust" (Landsberger 1934: 123-24). One variety of zizānu is known to have inhabited trees, as reported in the lexical text Urra XIV 235-236: buru ${ }_{5}$. gán-na = zi-za-nu, "ganna locust;" buru ${ }_{5}$.gán-(nu)-tir-ra = MIN qiš-tum, "zizānu of the woods." The verb of present line is to our eyes more probably ú-na-'-i (<nu" $\hat{u}$ “to wail” = [ír] gá-gá "to lament” in Kagal A i 8) than u-na-'i-r $[a]$ (despite 1. 308). Either way, the word tells us that these insects made a loud noise in the Cedar Forest, and raises the question of whether they were in fact cicadas (often known in the vernacular as "tree crickets"). Several varieties of cicada occur in the eastern Mediterranean and the Middle East. The principal characteristics of adult cicadas are that they sit in trees and create a tremendous chorus of noise.

29-30. This pair of narrative lines is a couplet also found in the Poem of the Righteous Sufferer ( $L u d l u l$ II 77-78) and already noted as related to SB V 44 (formerly IV 242, George 2003: 820), where the mood is precative.

35-50. These sixteen lines of direct speech follow a standard line, which announces that Gilgameš is speaking to Enkidu (V 34). However, now it is clear that it is Gilgameš, not Enkidu, whose strength has failed him (V 28-30), 1. 44 cannot sensibly be uttered by him and a change of speaker must have taken place somewhere between 1l. 36 and 44 . We suppose that the change is marked by the word ibri at the beginning of 1.39 , and that another such change is signalled when ibrī recurs in 1. 45. Repetition of ibri also occurs in 11.82 and 87 but, because the text is fragmentary, it is not certain that there it has the same function. Changes of speaker that are not indicated by a narrative line occur elsewhere in SB Gilgameš, at I 224 and VII 253; note also the unmarked quotation of Enlil's words by Enkidu newly revealed in V 305-6.

61. The line is restored with a standard combination of clauses that is used on two other occasions in SB Gilgameš when someone watching the approach of an unidentified person reflects on the identity of the watched: the ale-wife Šiduri observing Gilgameš arriving at her tavern (IX 11) and Ūta-napištī watching Gilgameš and Uršanabi sail towards his shore (X 185).

75. The line is restored after one of the fragments from Ugarit ( $\mathrm{MB} \mathrm{Ug}_{2} \mathrm{~b} 1^{\prime}$, see George 2007: 249).

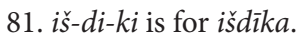

88. The line is restored as a proverbial saying that occurs as an apodosis in several lists of physiognomic omens and is also quoted in an Assyrian scholar's letter (instances collected by Heeßel 2010: 152; we owe both restoration and reference to Enrique Jiménez).

99. The restoration of $\check{s} a$ namrirrī is suggested by an Ugarit fragment ( $\mathrm{MB} \mathrm{Ug} \mathrm{g}_{2}$ c 10' // 21', see George 2007: 251). 250-51. These two lines are restored after the Old Babylonian tablet from Ishchali (15', ed. George 2003: 262): ib-ri i-șú-ra-am ba-ar-ma e-ša-am i-la-ku wa-at-mu-šu.

305-6. This couplet finds a near parallel in the unprovenanced Old Babylonian tablet now in Baghdad, where similar words are spoken by Enkidu to Gilgameš when proposing to make a door for Enlil's temple (OB IM 20-21, ed. George 2003: 268-69): i-na du-ni-ka-ma ma-șa-ra-am te-né-ra-am / mi-nu-ú-um ú-ba-ša-ka qí-iš-tam ša giš / šu-né-el, "By your strength alone you slew the guardian; what can bring you dishonor? The forest of [cedar] wood lay low!" In the present instance the speaker and addressee are the same, but the use of the second-person plural indicates that these words are placed, in anticipation, in the mouth of the god Enlil. The devastation of the forest is an affront to Enlil, and Enkidu is seeking a means to appease him.

307. As noted above, this line is the counterpart of OB Ishchali 35'b (George 2003: 264): iš-tu-ma se-bé-et i-neru.

308. Elsewhere in SB V, simurru is one of the winds that Šamaš sent to immobilize Humbaba (1. 162, formerly 139), but that is ill suited to the present context. Enrique Jiménez made the breakthrough with the brilliant suggestion that this line contains the names of Humbaba's sons (private communication). He compared it with SB V 160-63 (formerly 137-40) and Enūma eliš IV 51-52, where collective descriptions are likewise followed by lists of names. 


\section{References}

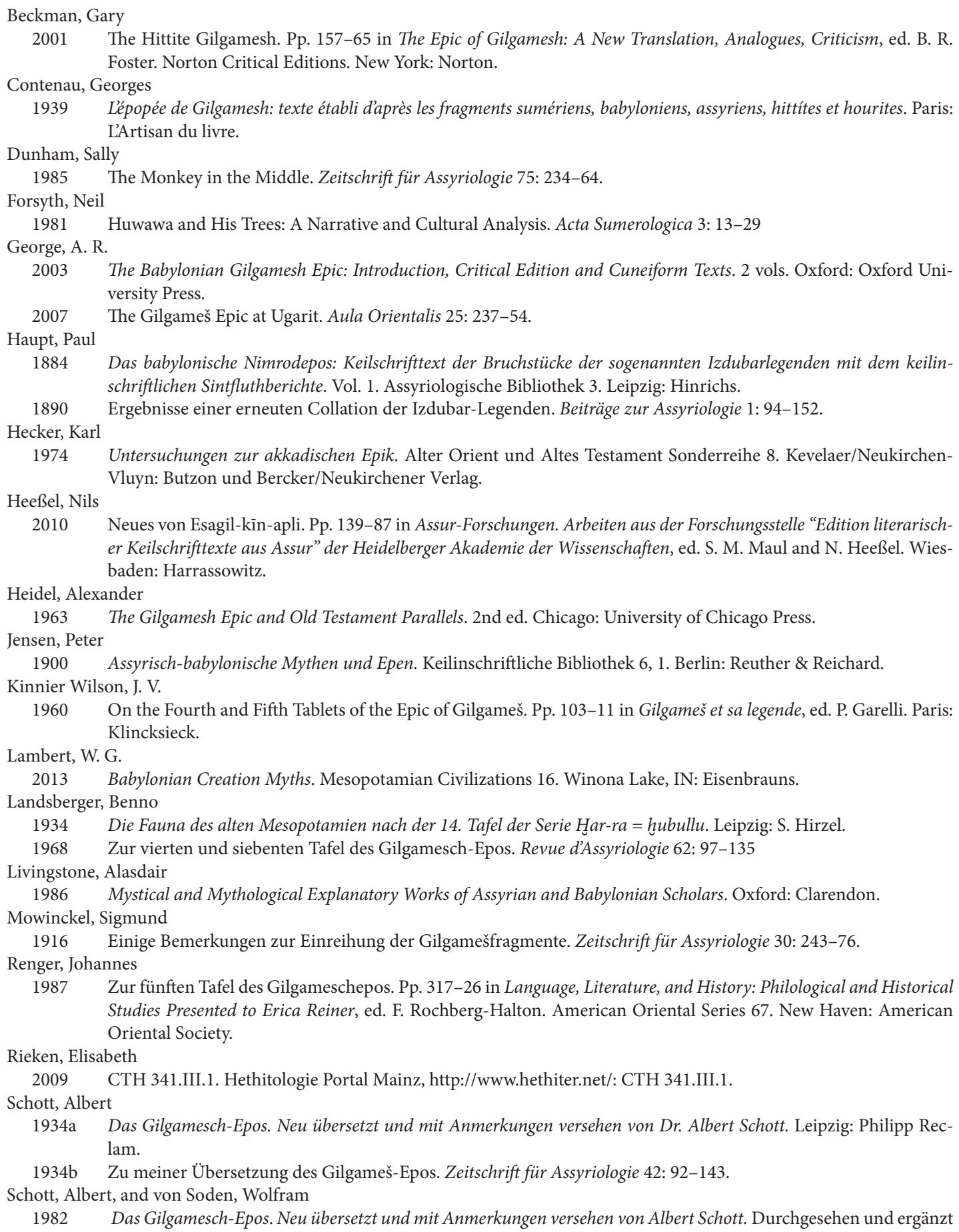


von W. von Soden. 3rd ed. Stuttgart: Philipp Reclam.

Smith, George

1876 The Chaldean Account of Genesis. London: Thomas Scott.

Soden, Wolfram von

1959 Beiträge zum Verständnis des babylonischen Gilgameš-Epos. Zeitschrift für Assyriologie 53: 209-35. Speiser, E. A.

1969 The Epic of Gilgamesh. Pp. 73-99 in Ancient Near Eastern Texts Relating to the Old Testament. 3rd ed. with Supplement, ed. J. B. Pritchard. Princeton: Princeton University Press. Spycket, Agnes

1998 "Le carnaval des animaux:" On Some Musician Monkeys from the Ancient Near East. Iraq 60: 1-10. Stol, Marten

2007 Fevers in Babylonia. Pp. 1-39 in Disease in Babylonia, ed. I. L. Finkel and M. J. Geller. Cuneiform Monographs 36. Leiden: Brill.

Streck, Michael P.

2007 Beiträge zum akkadischen Gilgameš-Epos. Orientalia 76: 404-23.

Thompson, R. Campbell

1930 The Epic of Gilgamish. Oxford: Clarendon.

Ungnad, Arthur

1911 Das Gilgamesch-Epos. Göttingen: Vandenhoeck \& Ruprecht.

Weiher, Egbert von

1980 Ein Fragment der 5. Tafel des Gilgameš-Epos aus Uruk. Baghdader Mitteilungen 11: 90-105. 


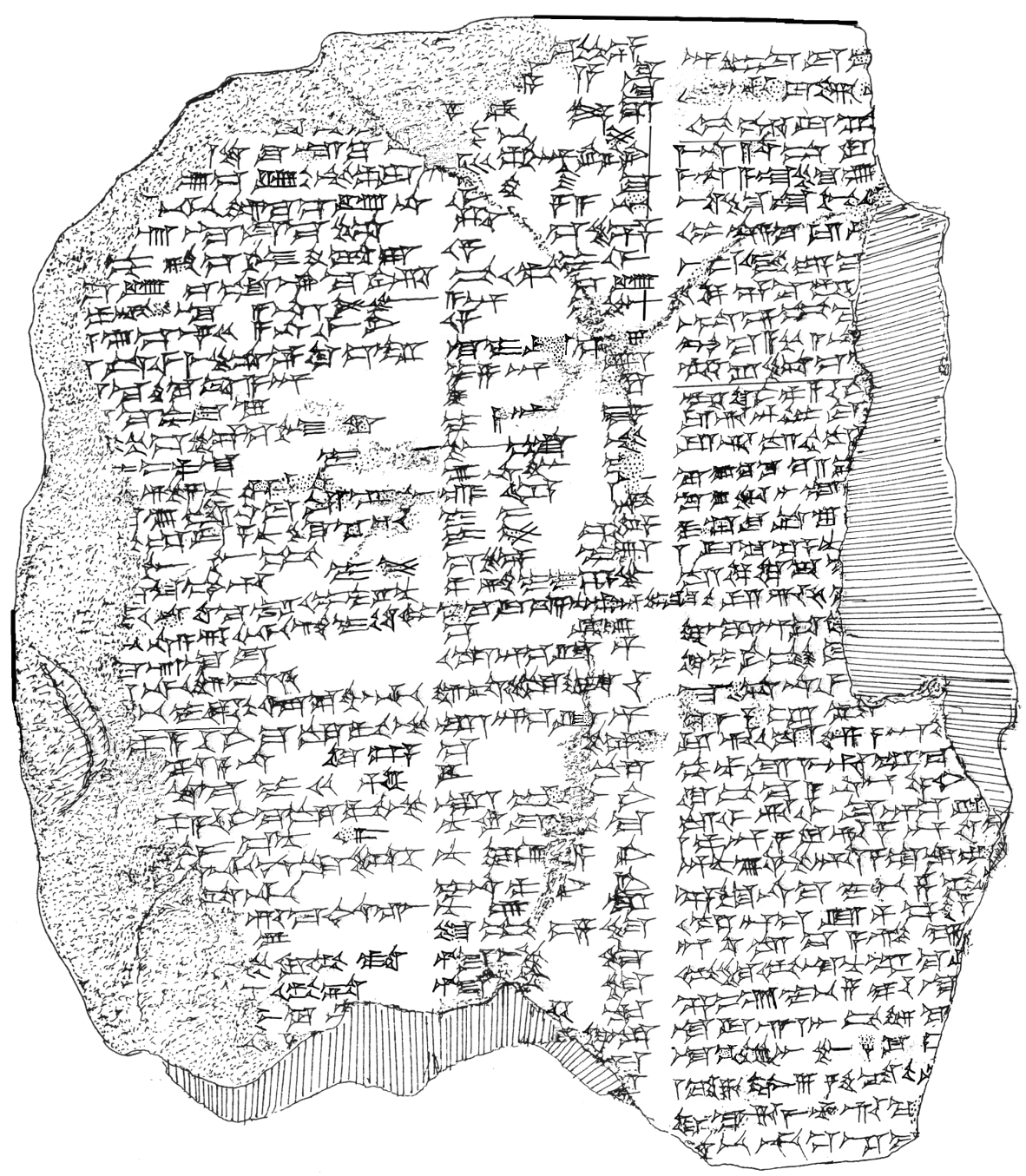

Fig. 2. Suleimaniyah Museum T.1447 = SB Gilg. V MS ff obv.; drawn by Al-Rawi 


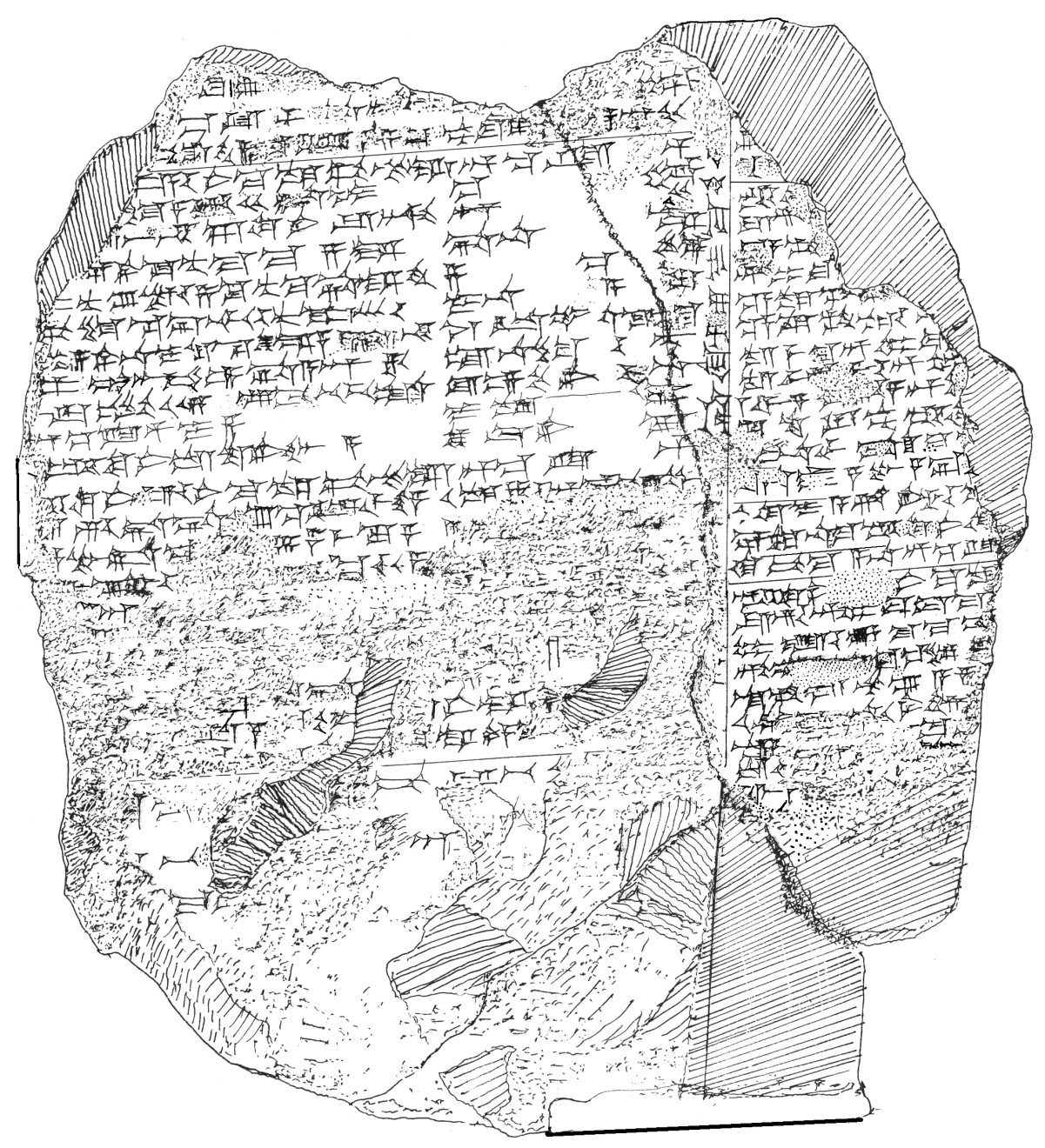

Fig. 3. Suleimaniyah Museum T.1447 = SB Gilg. V MS ff rev.; drawn by Al-Rawi 


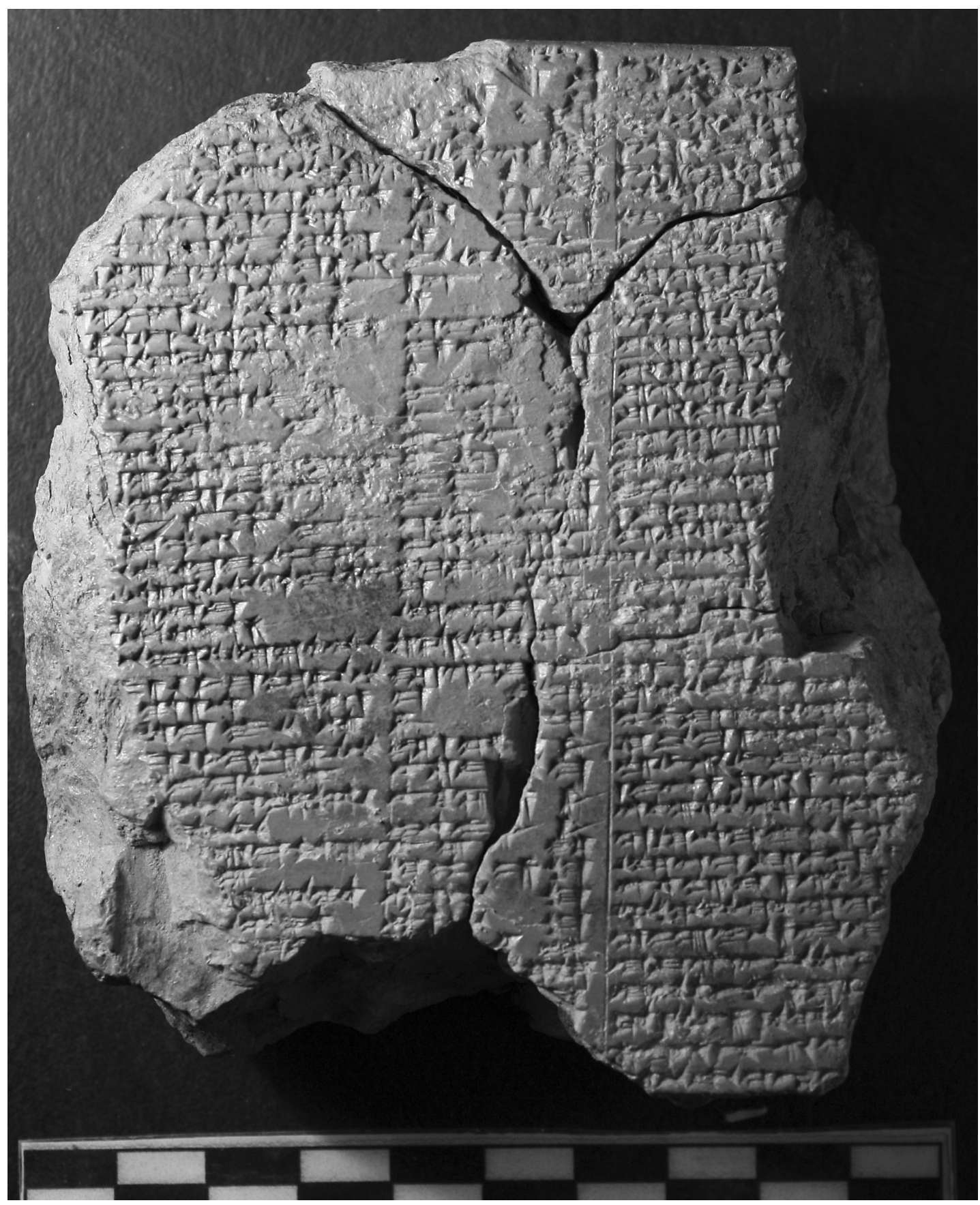

Fig. 4. Suleimaniyah Museum T.1447 = SB Gilg. V MS ff obv. 


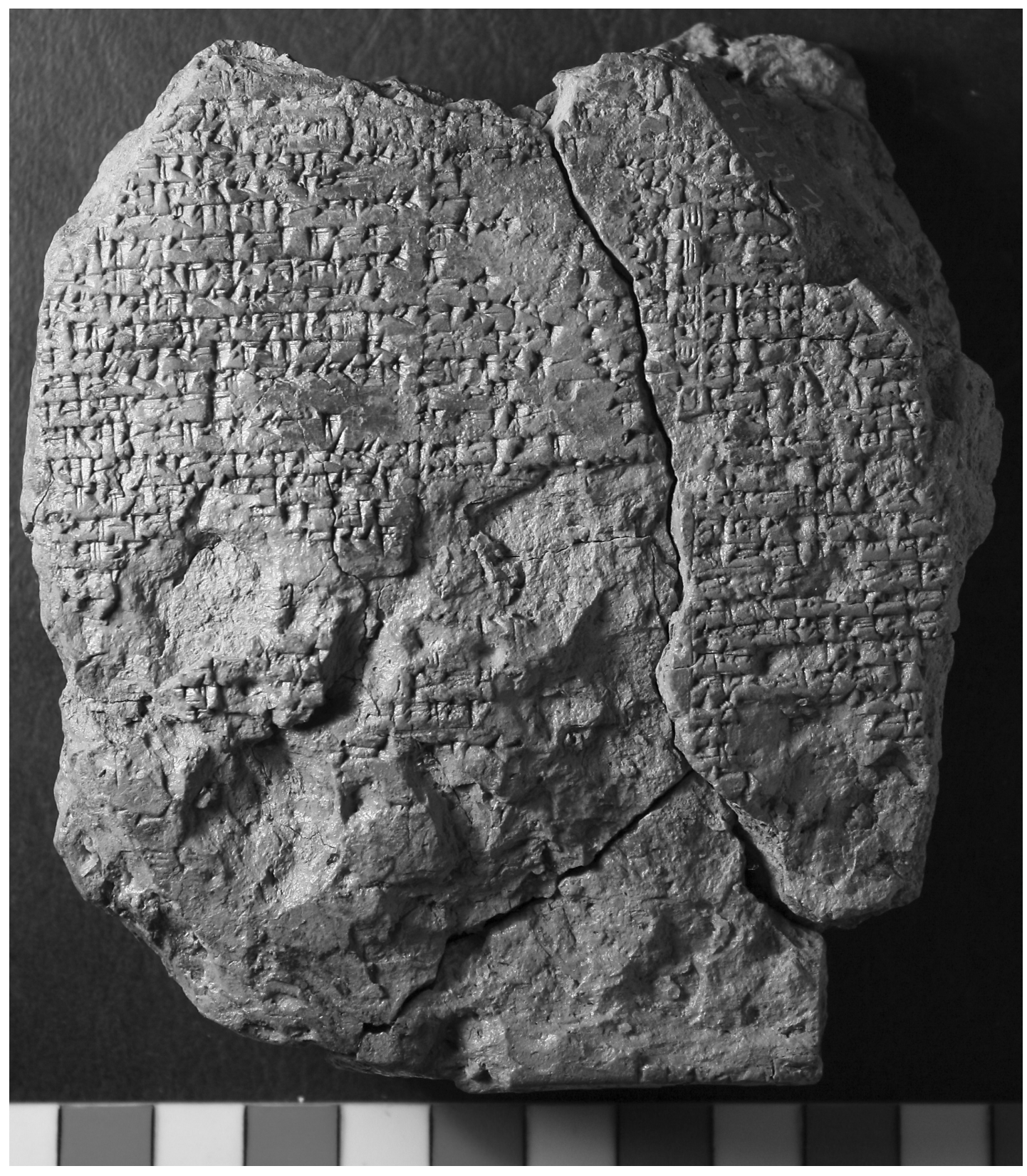

Fig. 5. Suleimaniyah Museum T.1447 = SB Gilg. V MS ff rev. 